\title{
Negative Pressure Wound Therapy in Postoperative Extensive Soft Tissue Necrosis after Spinal Surgery: Case Report
}

\section{Michail Yu Korostelev ${ }^{1}$, Sergey 0 Ryabykh ${ }^{2}$, Natalia G Shikhaleva ${ }^{3}$, Dmitry M Savin ${ }^{4}$ and Olga M Sergeenko ${ }^{4 *}$}

${ }^{1}$ Plastic Surgeon, Division of Plastic Surgery and Reconstruction, Ilizarov Center, Russia

${ }^{2}$ Spinal Surgeon, Division of Spinal Surgery, Ilizarov Center, Russia

${ }^{3}$ Orthopedic Surgeon, Division of Plastic Surgery and Reconstruction, Ilizarov

Center, Russia

${ }^{4}$ Neurosurgeon, Spinal Surgeon, Division of Spinal Surgery, Ilizarov Center, Russia

*Corresponding Author: Olga M Sergeenko, Neurosurgeon, Spinal Surgeon, Division of Spinal Surgery, Ilizarov Center, Russia.
Received: February 17, 2021

Published: March 10, 2021

(C) All rights are reserved by $\mathbf{0 l g a} \mathbf{M}$

Sergeenko., et al.

\begin{abstract}
We would like to share our experience with negative-pressure wound therapy (NPWT) usage in extensive wound necrosis after spinal surgery.

Our patient was a 7-years-old boy with segmental spinal dysgenesis, lower paresis, reduced lower extremities sensitivity, pelvic disorders, decrease of functional independence, psychomotor retardation and hypotrophy. The patient underwent vertebral column resection et Th11-L1 levels, Th6-L4 posterior screw fixation and $360^{\circ}$ spondylodesis, complicated by hemothorax, extensive postoperative wound necrosis and neurological deterioration. Wound healing in this case was achieved through the usage NPWT, complicated by spinal dural laceration and CSF leak. Fistula was repaired by sealing synthetic glue and fibrin sponge.

The usage of NPWT in case of necrotic complications in the spinal surgery may be a useful option, which allows saving implants, if there are any. It's important that NPWT may cause laceration of the dura mater, especially in cases where there is damage of the external dural layer. NPWT not contraindicated in cases of CSF leak episodes only if dural wound was closed and there are no signs of liquorrhea.
\end{abstract}

Keywords: Giant Pressure Ulcer; CSF Leak; Wound Necrosis; Spine Surgery Complication; Negative Pressure Wound Therapy

\section{Abbreviations}

ASIA: American Spinal Injury Association Scale; CSF: Cerebrospinal Fluid; mJOA: Modified Japanese Orthopedic Association Scale; NPWT: Negative-Pressure Wound Therapy; OR: Operating Room; VAS: Visual Analog Scale; WeeFIM: Pediatric Functional Independence Measurement Scale

\section{Introduction}

Patients with the spina bifida and paresis are inclined to the postoperative wound necrosis [1-3]. Loss of tissue innervations, physical inactivity and chronic urinal infection in case of spinal surgery play a significant role in tissue damage occurrence [2-6]. These include pressure sores, postoperative wound necrosis, poor wound healing and wound infection [7-9]. 
Negative-pressure wound therapy (NPWT) is a therapeutic technique using a vacuum dressing to promote healing in large wounds $[10-14]$.

\section{Materials and Methods}

Our patient was a 7-years-old boy with segmental spinal dysgenesis, lower paresis, reduced lower extremities sensitivity, pelvic disorders (ASIA motor 82, mJOA 14, VAS 0), psychomotor retardation and hypotrophy (weight $13.5 \mathrm{~kg}$, height $98 \mathrm{~cm}$, body mass index 13.8).

\section{Results}

The patient underwent Th11-L1 vertebral column resection, Th6-L4 posterior screw fixation and $360^{\circ}$ spondylodesis. The dural sac in the area of the anomaly was thinned to $6 \mathrm{~mm}$.

The duration of the operation was $185 \mathrm{~min}$ and blood loss 400 $\mathrm{ml}$. At the end of the procedure no signs of respiratory distress were noted. Intraoperative neuromonitoring showed instability of motor and sensory evoked potentials throughout the surgery.

The patient was left on the mechanical ventilation in the intensive care unit. Respiratory disorders appeared six hours after surgery. The chest CT showed right hemothorax. A chest tube was inserted with immediate drainage of $1200 \mathrm{ml}$ of bloody fluid accompanied by symptomatic relieve. The chest tube was removed after 4 days when hemothorax was fully defeated.

The patient was awakened 24 hours after the surgery, neurological deterioration was noted (ASIA motor 55, mJOA 10, VAS 8). The postoperative wound was located along the thoracic and lumbar spine, $21 \mathrm{~cm}$ long, with signs of tissue necrosis along its edges. The width of the necrosis of the skin was from 1 to $9 \mathrm{~cm}$, which had an irregular shape and occupied an area of up to $2 \%$ of the body surface (Figure 1a).

On $14^{\text {th }}$ day after initial surgery necroectomy was performed in operating room (OR) (Figure 1b). A sterile sponge was attached to the wound cavity in three layers, fixed to the tissues by sutures (Figure 1d). All area was sealed with a transparent waterproof dressing, in top of which a small hole was cut to attach the vacuum aspirator (Figure 1c). We set the pulse mode of the device with a minimum discharge mode: $45 \mathrm{mmHg} 2 \mathrm{~min}$ - $20 \mathrm{mmHg} 5 \mathrm{~min}$.
On the $1^{\text {st }}$ day of vacuum drainage liquorrhea was suspected, because of increasing the amount of bloody content $(300 \mathrm{ml}$ per night). Because of what the patient is taken to the OR to change the dressing. Stratification of the external dural layer over 4 x $1 \mathrm{~mm}$ along the posterior wall of the dural sac was noted. The duraplasty by "sandwich" technique was performed: direct closure by suture, a piece of fibrin sponge was laid on the defect, fibrin glue on top, then a layer of fibrin sponge and glue again. Then a silicone dressing and four layers of sterile sponge were laid on top and fixed by sutures to surround tissues. Such type of dressing made additional pressure on the dural defect area. Muscle plastic was performed additionally in the upper and lower parts of the wound: the muscles were stitched along the midline, excluding the zone in the middle part of the wound, where the muscles failed to connect due to lack of tissue. A sterile bandage was applied for five days. After we made sure that there was no liquorrhea the vacuum dressing was imposed by the previously described method. We set the pulse mode of the device at the same levels (minimal).

On $6^{\text {th }}$ day after start of vacuum drainage applying dressing was changed in OR. Active growth of granulations was noted (Figure $1 \mathrm{e})$. On the $8^{\text {th }}$ day after vacuum drainage applying, due to the absence of CSF leak, the pressure in NPWT dressing was increased to $60-100 \mathrm{mmHg}$. Before the skin plasty, 7 dressings (including changing of vacuum drainage) were performed. The wound was filled by granulations, bacterial cultures from the wound were negative (no wound infection occurred). On $25^{\text {th }}$ day after vacuum drainage applying the skin plasty was perfomed by 1-mm-thick split perforated skin graft from occipito-parietal region of the head. The graft is well established.

The total duration of patient treatment was 72 days. After 12 months follow-up, there were no signs of wound infection, bedsores, instability of construction and no progression of spinal deformity (Figure 1f). Neurological changes survived, some improvement was noted (ASIA motor 59, mJOA 11, VAS 1) compared to the preoperative level.

\section{Discussion}

The presence of a wound infection after spinal surgery with instrumentation is an indication for the use of NPWT [15].

The exact mechanism of action of negative-pressure involves: 1) increase in local blood flow; 2) removal of chronic wound fluid, in- 
Currently, there is a large number of works devoted to the

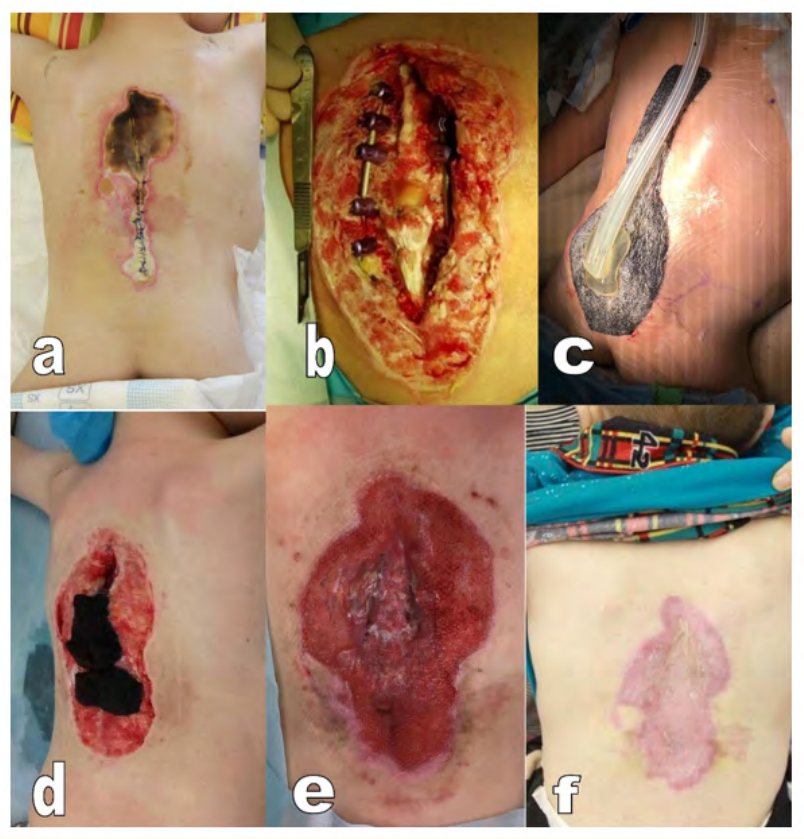

Figure 1: Photos of spinal wound changes during negativepressure wound treatment in 7-years-old patient with segmental spinal dysgenesis. a. Extensive wound necrosis on $14^{\text {th }}$ day after initial spinal surgery. b. Wound after necrectomy, that was perfomed on $14^{\text {th }}$ day after initial spinal surgery. c. Vacuum dressing views after beginnings of suction. d. Wound on second day after vacuum drainage applying: a sterile sponge was attached to the wound cavity in three layers, fixed to the tissues by 3-0 monofilament sutures. e. Wound was filled by granulations on day $8^{\text {th }}$ after vacuum drainage applying. f. Wound after 12 months follow-up: there were no signs of wound infection and bedsores.

cluding interstitial fluid, with reduction in local edema; 3) increases mechanical stress on the tissues, causing increased formation of granulation tissue $[16,17]$.

Contraindications for performing NPWT in patients after spinal surgery: risk of profuse bleeding from the wound area (coagulopathy, anticoagulant therapy, abundant spinal tumors), wound liquorrhea and fistulas, bandage allergy [18]. analysis of the use of NPWT in patients after spinal surgery (Table 1).

\begin{tabular}{|c|c|c|c|c|}
\hline & $\begin{array}{c}\text { № } \\
\text { patients }\end{array}$ & Age & Aim & Complications \\
\hline $\begin{array}{l}\text { Mueller., et al. } \\
2021 \text { [28] }\end{array}$ & 118 & Adults & $\begin{array}{c}\text { SSI } \\
\text { prevention } \\
\text { (SSI rate) } \\
3.4 \%\end{array}$ & 0 \\
\hline $\begin{array}{l}\text { Rickert., et al. } \\
2021 \text { [29] }\end{array}$ & 50 & Adults & SSI treatment & 0 \\
\hline $\begin{array}{l}\text { Akhter., et al. } \\
2020[30]\end{array}$ & 42 & Adults & $\begin{array}{c}\text { SSI } \\
\text { prevention } \\
\text { (SSI rate) } \\
7.1 \%\end{array}$ & 0 \\
\hline $\begin{array}{l}\text { Kurra., et al. } \\
2020[31]\end{array}$ & 23 & Adults & SSI treatment & 0 \\
\hline $\begin{array}{l}\text { Antony., et al. } \\
2004 \text { [32] }\end{array}$ & 16 & Adults & SSI treatment & 0 \\
\hline $\begin{array}{l}\text { Canavese., et } \\
\text { al. } 2009 \text { [33] }\end{array}$ & 14 & Ped & SSI treatment & 0 \\
\hline $\begin{array}{l}\text { Jones., et al. } \\
2007 \text { [34] }\end{array}$ & 14 & Adults & SSI treatment & 5 \\
\hline $\begin{array}{l}\text { Labler., et al. } \\
2006 \text { [35] }\end{array}$ & 15 & Adults & SSI treatment & 0 \\
\hline \begin{tabular}{|l} 
Mehbod., et al. \\
2005 [36]
\end{tabular} & 20 & Adults & SSI treatment & 0 \\
\hline $\begin{array}{l}\text { Ploumis., et al. } \\
2008 \text { [37] }\end{array}$ & 73 & Adults & SSI treatment & 2 \\
\hline $\begin{array}{l}\text { Van Rhee., et } \\
\text { al. } 2007 \text { [38] }\end{array}$ & 6 & Ped & SSI treatment & 0 \\
\hline $\begin{array}{l}\text { Yuan-Innes., et } \\
\text { al. 2001 [39] }\end{array}$ & 2 & Ped & SSI treatment & 0 \\
\hline \begin{tabular}{|l} 
Zehnder., et al. \\
2007 [40]
\end{tabular} & 11 & Adults & SSI treatment & 1 \\
\hline $\begin{array}{l}\text { Vicario., et al. } \\
2007 \text { [41] }\end{array}$ & 2 & Adults & SSI treatment & 0 \\
\hline $\begin{array}{l}\text { Horn., et al. } \\
2007 \text { [42] }\end{array}$ & 11 & Ped & $\begin{array}{c}\text { SSI } \\
\text { prevention }\end{array}$ & 0 \\
\hline $\begin{array}{l}\text { Hwang., et al. } \\
2011 \text { [43] }\end{array}$ & 5 & Adults & SSI treatment & 0 \\
\hline $\begin{array}{l}\text { Naylor., et al. } \\
2020 \text { [19] }\end{array}$ & 23 & Adults & SSI treatment & 0 \\
\hline
\end{tabular}




\begin{tabular}{|l|c|c|c|c|}
\hline $\begin{array}{l}\text { Ridwan., et al. } \\
2019 \text { [21] }\end{array}$ & 25 & Adults & SSI treatment & 0 \\
\hline $\begin{array}{l}\text { Dyuk., } \text { et al. } \\
2019 \text { [44] }\end{array}$ & 21 & Adults & $\begin{array}{c}\text { SSI } \\
\text { prevention }\end{array}$ & 0 \\
\hline $\begin{array}{l}\text { Zeng., } \text { et al. } \\
2019 \text { [45] }\end{array}$ & 16 & Adults & SSI treatment & 0 \\
\hline $\begin{array}{l}\text { Tamir., } \text { et al. } \\
2018 \text { [46] }\end{array}$ & 66 & Adults & SSI treatment & 1 \\
\hline $\begin{array}{l}\text { Lee., } \text { et al. } \\
2018 \text { [20] }\end{array}$ & 42 & Adults & SSI treatment & 0 \\
\hline
\end{tabular}

Table 1: Negative pressure wound therapy in spinal surgery.

It is not ultimately clear whether NPWT is safe for patients with intraoperative durotomy. There are small series of patients who have had this procedure without complications [19-21]. Nevertheless, this issue needs additional research. The clinical case presented by us is another confirmation that NPWT is safe in patients with a primarily repaired water-tight dural closure after intraoperative CSF leak.

Spinal dural repair through suturing in the setting of a spinal dural laceration is a technically demanding surgical skill, but most studies on this topic are devoted to cases in which the surrounding soft tissue is not damaged [22-27].

\section{Conclusion}

The usage of NPWT in case of necrotic complications in the spinal surgery may be a useful option. It's important that NPWT may cause laceration of the dura mater. NPWT not contraindicated in cases of CSF leak episodes only if dural wound was closed. NPWT at cases of CSF leak episode should be carried out at the lowest possible pressure after dural repair (40/20 mm Hg). Pressure can be increased only if CSF leak was not observed for a minimum of seven days during NPWT on minimal pressure levels.

\section{Conflicts of Interest and Source of Funding}

No funding was received for this research. All authors certify that they have no affiliations with or involvement in any organization or entity with any financial interest (such as honoraria; educational grants; participation in speakers' bureaus; membership, employment, consultancies, stock ownership, or other equity interest; and expert testimony or patent-licensing arrangements), or non- financial interest (such as personal or professional relationships, affiliations, knowledge or beliefs) in the subject matter or materials discussed in this manuscript. The authors declare no conflict of interest in this work.

\section{Ethical Approval}

All procedures performed in studies involving human participants were in accordance with the ethical standards of the institutional and/or national research committee and with the 1964 Helsinki declaration and its later amendments or comparable ethical standards.

\section{Bibliography}

1. Kreutztrager M., et al. "Outcome analyses of a multimodal treatment approach for deep pressure ulcers in spinal cord injuries: a retrospective cohort study". Spinal Cord 56.6 (2018): 582-590.

2. Vibert B., et al. "Congenital lumbar kyphosis with skin ulceration and osteomyelitis in a myelomeningocele child: a case report". Child's Nervous System: Chns: Official Journal of the International Society for Pediatric Neurosurgery 34.4 (2018): 771-775.

3. Pandey A., et al. "Neuropathic Ulcers Among Children With Neural Tube Defects: A Review of Literature". Ostomy/Wound Management 61.12 (2015): 32-38.

4. De Amoreira Gepp R., et al. "Kyphectomy in meningomyelocele children: surgical technique, risk analysis, and improvement of kyphosis". Child's nervous system: ChNS: official journal of the International Society for Pediatric Neurosurgery 29.7 (2013): 1137-1141.

5. Patel J., et al. "Correlation of spine deformity, lung function, and seat pressure in spina bifida". Clinical Orthopaedics and Related Research 469.5 (2011): 1302-1307.

6. Ouellet JA., et al. "Pressure mapping as an outcome measure for spinal surgery in patients with myelomeningocele". Spine 34.24 (2009): 2679-2685.

7. Dunn RN and Bomela LN. "Kyphectomy in Children With Severe Myelomeningocele-Related Kyphosis". Spine Deformity 4.3 (2016): 230-236.

8. Yoshioka K., et al. "Kyphectomy for severe kyphosis with pyo- 
genic spondylitis associated with myelomeningocele: a case report". Scoliosis 6.1 (2011): 5.

9. $\quad$ Niall DM., et al. "Kyphectomy in children with myelomeningocele: a long-term outcome study". Journal of Pediatric Orthopedics 24.1 (2004): 37-44.

10. Ge D. "The Safety of Negative-Pressure Wound Therapy on Surgical Wounds: An Updated Meta-analysis of 17 Randomized Controlled Trials". Advances in Skin and Wound Care 31.9 (2018): 421-428.

11. Tettelbach W., et al. "Use of mechanically powered disposable negative pressure wound therapy: recommendations and reimbursement update". Wounds: A Compendium of Clinical Research and Practice 31.2 (2019): S1-s17.

12. Yin D., et al. "Management of late-onset deep surgical site infection after instrumented spinal surgery". BMC Surgery 18.1 (2018): 121.

13. West JM., et al. "Instillation Negative Pressure Wound Therapy: An Effective Tool for Complex Spine Wounds". Advances in Wound Care 7.10 (2018): 333-338.

14. Yuan W., et al. "Management of Early Deep Wound Infection After Thoracolumbar Instrumentation: Continuous Irrigation Suction System versus Vacuum-Assisted Closure System". Spine 43.18 (2018): E1089-e1095.

15. Ousey KJ., et al. "Negative pressure wound therapy (NPWT) for spinal wounds: a systematic review". The Spine Journal: Official Journal of the North American Spine Society 13.10 (2013): 1393-1405.

16. Jones GA., et al. "Negative-pressure wound therapy in the treatment of complex postoperative spinal wound infections: complications and lessons learned using vacuum-assisted closure". Journal of neurosurgery Spine 6.5 (2007): 407-411.

17. Sato T., et al. "Factors impairing cell proliferation in the granulation tissue of pressure ulcers: Impact of bacterial burden". Wound Repair and Regeneration: Official Publication of the Wound Healing Society and the European Tissue Repair Society 26.3 (2018): 284-292.

18. Ousey KJ., et al. "Negative pressure wound therapy (NPWT) for spinal wounds: a systematic review". The Spine Journal 13.10 (2013): 1393-1405.
19. Naylor RM., et al. "Effects of Negative Pressure Wound Therapy on Wound Dehiscence and Surgical Site Infection Following Instrumented Spinal Fusion Surgery-A Single Surgeon's Experience". World Neurosurgery 137 (2020): e257-e262.

20. Lee R., et al. "The use of vacuum-assisted closure in spinal wound infections with or without exposed dura". European Spine Journal: Official Publication of the European Spine Society, the European Spinal Deformity Society, and the European Section of the Cervical Spine Research Society 27.10 (2018): 2536-2542.

21. Ridwan S., et al. "Safety and Efficacy of Negative Pressure Wound Therapy for Deep Spinal Wound Infections After Dural Exposure, Durotomy, or Intradural Surgery". World Neurosurgery 134 (2020): e624-e630.

22. Ghobrial GM., et al. "Simulated spinal cerebrospinal fluid leak repair: an educational model with didactic and technical components". Neurosurgery 73.1 (2013): 111-115.

23. Chou D., et al. "Primary dural repair during minimally invasive microdiscectomy using standard operating room instruments". Neurosurgery 64.5-2 (2009): 356-358.

24. Ferroli P., et al. "Use of self-closing U-clips for dural repair in mini-invasive surgery for herniated disc". Acta Neurochirurgica 150.10 (2008): 1103-1105.

25. Khan MH., et al. "Postoperative management protocol for incidental dural tears during degenerative lumbar spine surgery: a review of 3,183 consecutive degenerative lumbar cases". Spine 31.22 (2006): 2609-2613.

26. Risch L., et al. "Rapid, accurate and non-invasive detection of cerebrospinal fluid leakage using combined determination of beta-trace protein in secretion and serum". Clinica Chimica Acta; International Journal of clinical chemistry 351.1-2 (2005): 169-176.

27. Jankowitz BT., et al. "Effect of fibrin glue on the prevention of persistent cerebral spinal fluid leakage after incidental durotomy during lumbar spinal surgery". European Spine Journal: Official Publication of the European Spine Society, the European Spinal Deformity Society, and the European Section of the Cervical Spine Research Society 18.8 (2009): 1169-1174. 
28. Mueller KB., et al. "Effect of Incisional Negative Pressure Wound Therapy vs Standard Wound Dressing on the Development of Surgical Site Infection after Spinal Surgery: A Prospective Observational Study". Neurosurgery (2021): 040.

29. Rickert M., et al. "Management of Deep Spinal Wound Infections Following Instrumentation Surgery with Subfascial Negative Pressure Wound Therapy". Journal of Neurological Surgery Part A, Central European Neurosurgery (2021).

30. Akhter AS., et al. "Negative pressure wound therapy in spinal fusion patients". International Wound Journal (2020).

31. Kurra S., et al. "Outcomes of Negative Pressure Wound Therapies in the Management of Spine Surgical Site Wound Infections". International Journal of Spine Surgery 14.5 (2020): 772777.

32. Antony S and Terrazas S. "A retrospective study: clinical experience using vacuum-assisted closure in the treatment of wounds". Journal of the National Medical Association 96.8 (2004): 1073-1077.

33. Canavese F., et al. "Use of the vacuum assisted closure in instrumented spinal deformities for children with neuromuscular scoliosis who developed post-operative deep spinal infection". Developmental Medicine and Child Neurology 51.50 (2009): 03452-03452.

34. Jones GA., et al. "Negative-pressure wound therapy in the treatment of complex postoperative spinal wound infections: complications and lessons learned using vacuum-assisted closure". Journal of Neurosurgery: Spine 6.5 (2007): 407-411.

35. Labler L., et al. "Wound conditioning by vacuum assisted closure (VAC) in postoperative infections after dorsal spine surgery". European Spine Journal 15.9 (2006): 1388-1396.

36. Mehbod AA., et al. "Postoperative Deep Wound Infections in Adults After Spinal Fusion: Management with Vacuum-Assisted Wound Closure". Clinical Spine Surgery 18.1 (2005).

37. Ploumis A., et al. "Therapy of spinal wound infections using vacuum-assisted wound closure: risk factors leading to resistance to treatment". Clinical Spine Surgery 21.5 (2008): 320323.

38. Van Rhee MA., et al. "Vacuum-assisted wound closure of deep infections after instrumented spinal fusion in six children with neuromuscular scoliosis". The Spine Journal 7.5 (2007): 596600.
39. Yuan-Innes MJ., et al. "Vacuum-assisted wound closure: a new approach to spinal wounds with exposed hardware". Spine 26.3 (2001): E1-E4.

40. Zehnder SW and Place HM. "Vacuum-assisted wound closure in postoperative spinal wound infection". Orthopedics 30.4 (2007): 267-272.

41. Vicario C., et al. "Treatment of deep wound infections after spinal fusion with a vacuum-assisted device in patients with spinal cord injury". Acta Orthopaedica Belgica 73.1 (2007): 102.

42. Horn PL., et al. "Therapy in Pediatric Patients With Infected Spinal Wounds: A Retrospective Review". Orthopaedic Nursing 26.5 (2007).

43. Hwang J-H., et al. "Maggot debridement therapy for postsurgical wound infection in scoliosis: a case series in five patients". Spine 36.4 (2011): 313-319.

44. Dyck BA., et al. "Use of incisional vacuum-assisted closure in the prevention of postoperative infection in high-risk patients who underwent spine surgery: a proof-of-concept study". Journal of Neurosurgery Spine 31.3 (2019): 430-439.

45. Zeng J., et al. "Negative Pressure Wound Therapy Versus Closed Suction Irrigation System in the Treatment of Deep Surgical Site Infection After Lumbar Surgery". World Neurosurgery 127 (2019): e389-e395.

46. Tamir E., et al. "Outpatient Negative-Pressure Wound Therapy Following Surgical Debridement: Results and Complications". Advances in Skin and Wound Care 31.8 (2018): 365-369.

\section{Assets from publication with us}

- Prompt Acknowledgement after receiving the article

- Thorough Double blinded peer review

- Rapid Publication

- Issue of Publication Certificate

- High visibility of your Published work

Website: www.actascientific.com/

Submit Article: www.actascientific.com/submission.php Email us: editor@actascientific.com

Contact us: +919182824667 